\title{
PHILOSOPHY: A VERITABLE TOOL FOR RESCUING AFRICAN LEADERSHIP FROM THE LEGACIES OF COLONIAL ADMINISTRATION
}

\author{
Godfrey C. Asadu* \& Callistus C. Aguinam* \\ http://dx.doi.org/10.4314/og.v15i1.10s
}

\begin{abstract}
Today, many decades after independence, the much vaunted vision and mission of the African states to be among the most cherished states of the world, is far from being realized. The underdeveloped state of almost all African states is said to have at its basis poor leadership. The study reveals that the leadership challenge in Africa is not unconnected with her contact with colonialists. It is argued that the present political system of the continent is a direct reflection of the colonial system which is highly centralized and authoritarian in nature. It follows therefore, that the bad system of governance in Africa is attributable to colonial experience. To make head way, Africa has to free herself from the legacies of colonial administration. It is therefore, the firm intent of this paper to argue to the fact that philosophy has a vital role in reorienting Africans to create their own indigenous identity which not only settles the crisis of leadership but as well bring about the overall and much desired growth and development. It is a journey to critical self-awareness and self-realization made possible through philosophy.
\end{abstract}

Keywords: Leadership, Colonialism, Philosophy

\section{Introduction}

Africa is today in a precarious state owing to the event of colonialism that took place between 1800 and 1960s. Colonialism drastically altered the history of Africa. It brought about dislocation of the traditional conceptual paradigms, institutions and worldviews. This tragic experience left the African alienated and gave rise to loss of identity and no meaningful development. The African now wishes to concretize his social, political, religious, economic and cultural ideas to achieve the needed transformation and development. It is consequent upon this that this paper took a critical look at the contemporary leadership in Africa vis-a-vis colonial legacy. The 
Asadu \& Aguinam: Philosophy: A Veritable Tool for Rescuing ...

study reveals that the political system in Africa today is an offshoot of colonial system of administration characteristically authoritative, exploitative, centralized, autocratic, and bereft of the interest of the colonized states. The study therefore attributes the poor leadership in Africa which culminated to underdevelopment to colonial influence. The study thereby offers philosophy as the veritable tool to decolonizing African leadership. The outcome of the decolonization exercise would birth a political system based on the culture and value system of the traditional African resulting to the total transformation and the development of Africa, the study concludes.

\section{Definition of Terms}

Here the work is to concentrate on operationalization of certain concepts that will be adopted in the course of this work. The aim is to help the reader come to terms with the specific way such concepts are being employed in the work. The terms we shall conceptualize are leadership, colonialism and philosophy.

\section{Leadership}

Northhouse (2010:3) defines leadership as "a process whereby an individual influences a group of individuals to achieve a common goal." what this implies is that the notion of inspiring and motivating people to work for the good of the community is paramount in the idea of leadership. In the same vein Hersey and Blanchard (1988:86) stated while defining leadership in the works of George R Terry that "leadership is the activity of influencing people to strive willingly for the group objectives." What appears common in the above definitions is the fact that leadership involves an influential process of achieving a common goal. This shows that the leader must be able to inspire others to work for collective good. In this sense the interest of the community comes before the interest of the individual. This can be gleaned from the popular words of Mbiti where he propagates the communalistic view that 'I am because we are and since we are therefore I am.' What this shows is that in the relationship between the community and the individual the community stands in a preeminent position over the individual. In a simply way we shall understand leadership in this work to imply the ability of an individual to influence, motivate and enable others to 
Ogirisi: a new journal of African studies vol. 15s 2019 contribute towards the effectiveness and success of the organizations of which they are members or country to which they belong.

\section{Colonialism}

Colonialism is that part of historical epoch that pertains to Africa and some Asian countries which bears much negative impact on them. This actually changed the course of history for Africans to the extent that no African man would like what happened then to repeat itself. The different activities that dominated that moment were so in-humanistic, deceptive and brutal to the extent that no one can appropriately account for the number of resources that were looted from the African soil. The ripple psychological effects are still being felt in Africa today after many decades of self-government. It is in this line of thought that Oguejiofor (2001:32) emphasized that much of the political structure that today operates in almost the entire African continent originates from its colonial past. This shows succinctly the after effect of colonial rule. Colonialism can be seen as the "extension of political and economic control over an area by a state whose nationals has occupied the area and usually possess organizational or technological superiority over the native population." From this definition one may be able to deduce the pressing factors that run through it as thus: 'dominancy' and 'power'. Little wonder Ocheni $(2012: 46)$ has it that the first objective of colonialism is political domination. These two key words are the working agenda of the colonial masters to any place they surfaced. This experience took effect with the partitioning of African states in the Berlin conference of 1884/1885. It is important for us to note that what actually motivated colonialism was the need for raw material and market for surplus products which came with the industrial revolution.

\section{Philosophy}

The term philosophy like most terms in social sciences does not lend itself to a generally acceptable definition. However, one of the means of navigating through the difficulty of giving a consensual definition of philosophy is to understand its etymological meaning. Etymologically, philosophy means love of wisdom. This implies that a lover of wisdom (philosopher) must be a seeker of truth. It is impossible to behold a seeker of truth who does not ask questions. 
Asadu \& Aguinam: Philosophy: A Veritable Tool for Rescuing ...

Hence, this brings out one of the basic characteristics of philosophy which is its criticality. It is this that made Ezeani (2005:12) to see philosophy as "...primarily an intelligent and pragmatic questioning or inquiry." What he termed Iquism. It is through the process of critical questioning and reflection, the philosopher attempts to confront his or her existence, his or her immediate environment, challenge other people's assumptions and also contribute to the development of thought. It is this role of philosophy which Oguejiofor (2005:13) noticed when he says that philosophy "... is not just a theoretical, armchair ability to analyze and understand reality. It includes, as evident in Plato, a conviction about the ability of philosophers to practically change the course of human affairs for the better; to create the ideal state...." This is basically the role philosophy intends to play in this write up - to question the status quo in order to chart a new course for leadership in African society.

\section{The Impact of Colonialism on African Leadership}

Africa never remained the same after her contact with the colonial masters. In fact, Africa lost everything African and embraced the life pattern, culture, political structure, education system and everything Western. Describing the post-colonial Africa, Julius Nyerere; the former president of Tanzania and a Tanzanian anti-colonial activist writes:

African people have been shaped as much by their own part, shrouded in mist though much of it still is, as they have been by the contact with the West... we are what all our past, known and unknown, has made us. We and our grandfathers and our great grandfathers, have learned and adapted from nature, from ourselves, and from the peoples of Europe, America and Asian. (Nyerere; 1965:116)

The impact of colonialism on Africa was felt greatly on her political structure (as to other sectors). Scholars have argued that the political system in Africa today is a carryover from colonial system of administration. Africa in the pre-colonial era saw a political system that was highly African, that is, based on the culture of the African people. Then, communalism used to be the bedrock and the result of the wonderful relationship prevalent in African communities. Life in 
the African traditional setting, in its various facets, manifests itself in different forms which reflect communalistic tendencies. The individual, for instance, lives in the community, by the community and for the community. This means that an individual lives a life quite inseparable from the rest of the community. It is an 'I-We' relationship whereby the individual is both a relational being and a being in the society. There existed a spirit of oneness or unity of purpose that accounts for the peace, progress, love, etc among the pre-colonial Africa.

However, the whole story changed with the western invasion of African states. The colonialists had set out to achieve two main objectives, namely; 'the political domination' and 'the exploitation of African state'. These two objectives are highly interconnected since the political domination paves way for the exploitation of African states. Consequently, their first move was to replace the indigenous political system with theirs which is totally alien to the Africans. Unlike the pre-colonial African political administration which was highly democratic, the West adopted a more centralized and authoritarian system of administration. Copson (2001:12) described the colonial state in Africa as "an authoritarian bureaucratic apparatus of control and not intended to be a school of democracy". This underscores why there was no such concept as African popular participation during the colonial era.

It is so worrisome that the post-colonial African states adopted the colonialist's political system which was in no way in the interest of Africans rather a system meant to keep Africa in perpetual slavery and perjury. In the words of Wyle (2007:3): "the contemporary state in Africa is a remnant of a colonially imposed system. African states adopt the colonialists' centralized state which produced ethnic and authoritarian based political culture". Ethnic division which the colonial system promulgated left persistent rivalry and conflict in the African states thereby resulting in the exclusion and marginalization in African political societies. "The fragmentation of ethnic identities into several states and the uneven socio-economic development among several ethnic groups become an obstacle to manage diversity (Kidane, 2011:15-16). Political appointments are given not on merits but based on ethnic affiliate. Worse still, there is hatred among ethnic groups that it is almost impossible to co-exist as a nation-state. Inter-ethnic wars have hit 
Asadu \& Aguinam: Philosophy: A Veritable Tool for Rescuing ...

many African states thereby destabilising the economy of such states. Politics are played based on ethnic affiliation and no longer on merit; appointment and contracts are now politicized.

The fact that African leaders are highly corrupted is as well traceable to the legacy of colonialism. The colonialists from the outset never had the interest of Africa at heart. The reason is not farfetched; they stick strictly to their motive which is to suppress and exploit Africa. Such administration could best be described as 'Eurocentric' as 'the desires or needs of the colonized people were never allowed to prevail against those of the colonial power and its people" (Nyerere, 1965: 8). It follows therefore that the contemporary African leaders are playing the script of the colonial masters. They cling to political power strictly for their selfish interest and seek to do everything possible to achieve such. African leaders commit all sorts of atrocities to wield power and to retain power. The interest of the masses and the development of the state which ought to be the primary goals of every government are highly neglected. Instead, power tussle, nepotism, ethnic bigotry, oppression, corruption, incompetency, murder, and all assorts of evils are enthroned.

The adverse effect of colonialism on African leadership is the major cause of stalement in the development of African states. In the words of Obasola (2002:10) "no nation has achieved meaningful development socially, politically or economically without the input of or effective leadership". It is time for the African to think inwardly, and stop blaming the west for their continuous failure. Africa is in urgent need of reconstruction which must be based on culture and value system of the Africans. Her political system must reflect the need of the Africans and jeered towards the overall growth and development of Africa. Philosophy as a reconstructive discipline is at the fore burner of this task.

\section{Philosophy: A Panacea for the Decolonialization of African Leadership}

In his work, Democracy and Development in Africa, Claude Ake, a foremost Marxist intellectual and political economist argues that beyond every other factors contributing to the stagnation or regression of African economies stands "the political conditions in Africa" (Ake, 1996:1). The political condition of Africa as argued in 
the preceding section was birthed by colonialism which was in turn responsible for Africa's backwardness. To achieve the needed growth and development decolonization exercise is inevitable. It is consequent upon this that this section offers philosophy as a veritable tool for decolonizing African leadership. By decolonization, we mean divesting African leadership of all undue influences resulting from colonization. The role of philosophy at realizing this goal is indispensable.

First, philosophy commonly defined as 'the mother of all knowledge' aims not only at analyzing and criticizing every thought, belief, value, assumption, etc but also at finding solution to human problems. On this preview, philosophy becomes 'problem solving enterprise'. In the words of Oladipo (1955:5) "philosophy and indeed, philosophers should put philosophy in the service of human well-being through a critical and reconstructive scrutiny of the ideas we live by". Corroboratively, Oraegbunnam (2006:239) records that:

Philosophy must help in constructing a spirit of
critical acceptance or rejection of ideas that are
imported wholesale from Europe and America.
Sometimes, these ideas do not fit into the African
circumstances and labenswelt, but are accepted in the
blind supposition that everything European or
American is the better.

The process of divesting African leadership from undue influences emanating from her colonial past starts with the development of the individual; the African. Here, philosophy plays a vital role owing to the fact that philosophy as a discipline considered from any angle is in essence, a subject aims at developing man, who in turn takes the responsibility of developing his nation. This explains the synergy between human development and nation development or nation building. In the light of this, Nnamdi opines:

When we talk of national development, we have to remind ourselves that the nation is only real and concrete in terms of people that constitute it... development is people centred, it means that the people that make up the nation, the individual men 
Asadu \& Aguinam: Philosophy: A Veritable Tool for Rescuing ...

and women, are both the agents and beneficiaries of development. The role of philosophy therefore is in the moulding of character of individual (Nnamdi 2011)

Nnamdi was speaking in corroboration with Aristotle who had earlier stated that 'the society will definitely be a better place and the nation will be well developed if all her citizenry, and especially her key decisions and policy makers were to think, plan, act and choose in a way that is rational'. By this Aristotle re-echoes the special role of philosophy in search for human development through the moulding of minds and mindsets. What is meant here is that philosophy helps in the cultivation of rational, reflective and critical mind. This is therefore in tandem with the submission of Ekei (2007:13) who stated that "for development to thrive, the mindsets of those that govern Nigeria (Africa) must be formed and imbued with moral and intellectual visions".

The end product of this decolonizing exercise is the growth and development of African states. Consequently, the four main branches of philosophy provide us with the necessary tools to engender this much cherished development. Epistemology stands to help man acquire knowledge which helps him transform his society. This underscores the saying credited to Francis Bacon that 'knowledge is power'. It is through the power of knowledge that man generates solution to his existential problems. Ethics, another branch of philosophy, which strictly speaking is under the main umbrella, Axiology seeks to institute and protect the universality of the concept of right and wrong, good and bad. It follows as Nnamdi argues that "if ethics and ethical judgements are given prime position in the nation by all, key problems hindering the growth of the nation like corruption, bribery, extortion, misuse and abuse of public offices and public funds, truancy and so many evils confronting society will be a thing of the past (Nnamdi, 2011). The next branch, logic vests man with the critical mind. It is the study of the principles used in differentiating correct and incorrect reasoning, the basis of which rational judgements are made. A nation with reasonable and logically sound law rightly implemented remains but underdeveloped. Lastly, metaphysics gives man the needed perception and guidance for his thought and action. It is undeniable 
that a careful and pragmatic adherence to the dictates of these branches of philosophy would not only shake Africa off the undue colonial legacies but as well bring about the overall growth and development.

Besides the branches, philosophy discharges its function of decolonizing African leadership through 'comparative analyses' which according to Wiredu (1972:4) involves three levels of analyses:

First, a critical analysis of traditional African culture with a view to identifying and separating the undesirable elements of culture from those that are desirable and worth keeping. Second, a critical assessment of western culture and techniques, which is done with a view to identifying the aspects that are desirable and those that are suitable for social development in contemporary African society. The third level of analysis consists in the comparison of the western traditional culture and the African traditional culture. This would reveal the features that are generally western and those that are particularly African.

Be that as it may, the role of African philosophy at fostering a formidable leadership in Africa cannot be denied. Makamba is of the view that Africa philosophy must be at the forefront in the very exercise of decolonizing African leadership. His words are as thus:

African philosophy needs to recognise the history of its people, however unpleasant it may be. There is need for a 'colonial turn-around' by this I mean there is need to amplify the possible gain from the colonial experience without downplaying its negative effects. But the negative effects of colonisation should not be an obstacle to Africa's progress, much less to the development of its philosophy (Makamba 2007:14)

He equally noted that the task of re-finding and re-creating African identity which has been dispersed by the monster of colonialism is strictly the mission of the national ideological philosophy, a trend of African philosophy. By re-finding African philosophy, he means 
Asadu \& Aguinam: Philosophy: A Veritable Tool for Rescuing ...

affirming and defining a mode of cognition of that identity (Ibid; 116). But how far has this journey of re-finding and re-creating the African identity gone? Africans and indeed, African philosophers must go beyond creating theories/policies to applying/implementing them to achieving societal transformation. The rediscovery of African identity is pertinent for a holistic emancipation of African leadership and African states.

\section{Conclusion}

Our journey so far exposes the ills of colonialism on African leadership which metamorphosed to the developmental challenge in Africa today. Africa is therefore in the urgent need of shaking off undue influence of colonialism. Philosophy was offered as a requisite tool to decolonizing African Leadership. The choice of philosophy for this special task is based on the fact that philosophy offers solution to the problems of man through the critical and reconstructive scrutiny of ideas. More so, philosophy through the instrumentality of its branches equips man with the necessary tools to transform his society. The work of re-finding and re-creating African identity lost by colonial invasion is the sole task of philosophy precisely, African Philosophy. When African identity is restored and a system of governance enacted based on African culture and value system; then would the desired transformation assured.

\section{* Godfrey C. Asadu}

Bigard Memorial Seminary, Enugu

Email: asadugodfrey@gmail.com

\&

*Callistus C. Aguinam

Nnamdi Azikiwe University Awka

Email: bukas2020@gmail.com 


\section{References}

Ake, C. (1996). Democracy and Development in Africa. Ibadan: Spectrum Books.

Copson, R.N. (2001). African Backgrounder: History, U.S. Policy, Principal Congressional Actions. In E. Bayeh,The Political and Economic Ledacy of Colonialism in the Post-Independence African States, International Journal in Commerce, IT, \& Social Sciences, Vol.2, Issue-2 (2015), ISSN:3394-5702.

Ezeani, E. (2005) Philosophy as intelligent and pragmatic questioning. London: Veritas Lumen Publishers.

Hersey, Paul and Blanchard, Ken. (1988) Management of organizational Behaviour, Prentice Hall Inter, Inc; CA, USA. P. 86

Makumba,M. (2007). Introduction to African Philosophy. Kenya: Paulines Publications Africa.

Nnamdi, B.S. (2011). Selected Themes in Logic and Philosophy. PortHarcourt: University of PortHarcourt Press.

NorthHouse, P. G (2010). Leadership: Theory and practice $\left(5^{\text {th }}\right.$ ed.). Thousand Oaks, CA: SAGE.

Nyerere, J. (1965). Freedom and Unity. Nairobi: Oxford University Press.

Kidane, K. (2011). Critical Factors in the Horn of Africa's Raging Conflicts. In E. Bayeh

Ocheni S. and Nwankwo B.C (2012). Analysis of colonialism and its impact in Africa. Cross-cultural Communication. P.46

Oguejiofor, J.O (2001) Philosphy and The African Predicament. Ibadan: Hope Publications.

Oladipo, O. (1995). Introduction to Decolonization in African Philosophy. Ibadan: Hope Publications.

Oraegbunam, I.K.E. (2006). Western Colonialism and African Identity: The Role of African Philosophy. In I. Odimegwu (ed.), Philosophy and Africa (pp. 220-235). Awka: Lumos Nigeria limited

Wiredu, K. (1972). On an Orientation in African Philosophy. Second Order,2,4.

Wyk, J. (2007). Political Leadership in Africa: Presidents, Patrons or Profiteers? In E. Bayeh.

http://exbition.nypl.org/africaage/essay-colonization-ofafrica.html. Accessed March 12th, 2019 